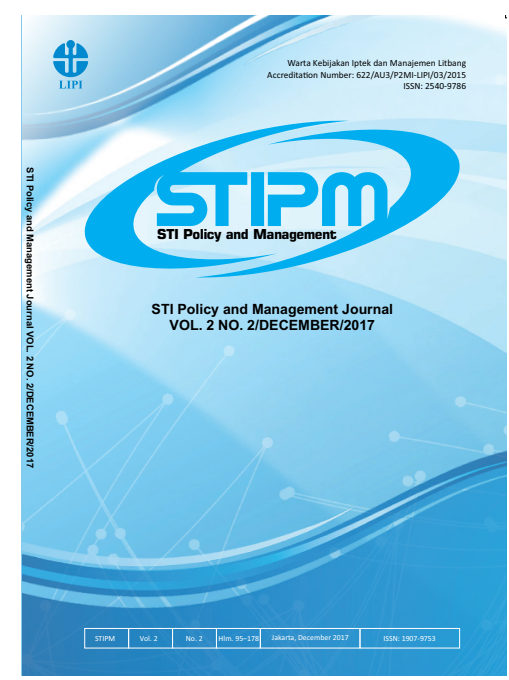

Journal of STI Policy and Management

Publication details, including instructions for authors and subscription information: http://www.stipmjournal.org/

\title{
Building Capacity for Innovation through R\&D Consortia in Health Projects: From Network Interaction to Systematic Transformation
}

\author{
Ria Hardiyati, Trina Fizzanty, Erman Aminullah \\ Indonesian Institute of Sciences (LIPI), Indonesia
}

Version of record first published: 15 December 2017

To cite this article: Hardiyati, R., Fizzanty, T., and Aminullah, E. (2017). Building Capacity for Innovation through R\&D Consortia in Health Projects: From Network Interaction to Systemic Transformation. Journal of STI Policy and Management, 2(2), 139-148

To link to this article: http://dx.doi.org/10.14203/STIPM.2017.121

ISSN 2540-9786 (Print); ISSN 2502-5996 (online)

Accreditation Number: 622/AU3/P2MI-LIPI/03/2015

Full terms and conditions of use: https://creativecommons.org/licenses/by-nc-sa/4.0/

You are free to:

- Share : copy and redistribute the material in any medium or format

- Adapt : remix, transform, and build upon the material

- The licensor cannot revoke these freedoms as long as you follow the license terms.

Under the following terms:

Attribution - You must give appropriate credit, provide a link to the license, and indicate if changes were made. You may do so in any reasonable manner, but not in any way that suggests the licensor endorses you or your use.

$\$$ NonCommercial - You may not use the material for commercial purposes.

(3) ShareAlike - If you remix, transform, or build upon the material, you must distribute your contributions under the same license as the original.

No additional restrictions - You may not apply legal terms or technological measures that legally restrict others from doing anything the license permits.

Notices:

- You do not have to comply with the license for elements of the material in the public domain or where your use is permitted by an applicable exception or limitation.

- No warranties are given. The license may not give you all of the permissions necessary for your intended use. For example, other rights such as publicity, privacy, or moral rights may limit how you use the material.

- If you copy the dataset merely to extract the uncopyrightable data elements would not need permission to do so. However, if you republish the full dataset or using the copyrightable data layers require a permission from PAPPIPTEK-LIPI. 


\title{
JOURNAL OF SCIENCE, TECHNOLOGY AND INNOVATION POLICY AND MANAGEMENT (STIPM JOURNAL), Volume 02, Number 02, December 2017
}

\author{
FOREWORD by EDITOR-in-CHIEF
}

We are pleased to present the STIPM Journal Vol. 2, No. 2, December, 2017. This issue brings together research findings on the adoption of science, technology, and innovation policy and management from Thailand, Malaysia, and Indonesia. This issue also presents a theoritical review on the determinants of enterpreneurial success.

In the original articles of this issue, Poolsak Koseeyaporn et al. presented the Talent Mobility Programme in Thailand. It is a new programme for making relationship between the researchers, who are mostly working at Public R\&D institutions and universities/higher education institutions, and companies. This programme is supporting the researchers to connect, meet, and explore the possibility of having research topics that fulfill both interests of researchers and the companies. The researchers would have a chance to be exposed to the industry's research problems as well as to obtain a level of trust from the companies.

Wati Hermawati and Ishelina Rosaira present the result of an exploratory study on the factors contributing to the sustainability of renewable energy projects in the rural areas. It was indicated that the success of energy technology implementation lays not only in good technology performance and long-term maintenance, but was also highly dependent on six key factors, namely (1) project planning and development; (2) community participation; (3) active communication and beneficiaries; (4) technology maintenance, including workshop and technician availability; (5) project management and institutionalisation; and (6) local government support and networks. The findings from this study provide useful insights to all stakeholders involved in the implementation of renewable energy technology for the rural areas in Indonesia.

Thiruchelvam presents a brief overview on Malaysia's STI achievements, salient features of the nation's national innovation system (NIS), and the key challenges of its NIS. The central theme of the paper is that success in STI is not automatic. It must be made through effective policies in promoting innovation as well as innovations in policy-making itself. Without such commitment for these two sides of innovation policy-making, pouring more resources to the development of STI will be futile.

Ria Hadiyati, et al., discussed the innovation capacity-building in the health sector in Indonesia. Current initiatives to enhance innovation capacity exists by intensifying R\&D consortia in life science, especially vaccine and stem cell. The research capacity in the area of vaccines has been long started from individual research conducted by researchers. It has been continued into research organisations, and then developed into building innovation capacity through R\&D consortia. In areas of stem cell, there is still lack of evidence however, efforts have been made to build innovation capacity through R\&D consortia.

Emyana Ruth and Faiq Wildana compare the management of Indonesian ICT Business Incubators from the perspective of administrators and tenants. The incubation administrators emphasise the 
importance of aspects of skill development, synergy, and seed capital. Meanwhile, from the tenants' perspective, skill development services are considered quite satisfying, either in government, private, or university-owned business incubators. However, emphasising on skill development aspect might lead incubators to provide oversized portion on training activities and susceptible to be trapped as a training institute.

Dyan Vidyatmoko and Pudji Hastuti propose a theoretical framework as a result of the development of theoretical framework, proposed by Kiggundu as well as Lussier and Halabi. The proposed framework is to examine factors affecting the success of entrepreneurship development in Indonesia. Three factors are discussed simultaneously, namely the entrepreneurs, the entrepreneurial firms, and the external environment. Success is represented by three indicators consisting of employment growth, profitability, and survival. Compared to both models, the proposed approach is expected to provide a comprehensive analysis of the factors affecting the success of entrepreneurship development in Indonesia. The results of the study is relevant and useful, both from the academic and practical points of view. It also has practical contribution for policy makers in terms of conceptualising and operationalising appropriate factors for the success of entrepreneurship in Indonesia.

After indexing by Google Scholar, ISJD, and IPI, STIPM Journal is now indexed with DOAJ, BASE, and OCLC World Cat. This has made the journal dissemination wider. We would like to thank all the reviewers for their excellent work and the authors who have kindly contributed their papers for this issue. We are also indebted to the STIPM Journal editorial office at Pappiptek LIPI and the publishing and production teams at LIPI Press for their assistance in the preparation and publication of this issue.

We expect that STIPM will always provide the highest scientific platform for the authors and the readers, with a comprehensive overview on the most recent STI Policy and Management issues at the national, regional, dan international levels.

Jakarta, December 2017

Editor-In-Chief 



\section{JOURNAL OF STI POLICY AND MANAGEMENT}

Volume 2, Number 2, December 2017

\section{LIST OF CONTENTS}

An Empirical Study of Policy Implementation of Thailand Talent Mobility Programme

Poolsak Koseeyaporn, Kittisak Kaweekijmanee, Arum Kitipongwatana,

and Oraphan Wiarachai

Key Success Factors of Renewable Energy Projects Implementation in Rural Areas of Indonesia

Wati Hermawati and Ishelina Rosaira

Mobilizing Science, Technology and Innovation (STI) for Socio-Economic Development:

The Experience of Malaysia

K. Thiruchelvam

Building Capacity for Innovation through R\&D Consortia in Health Projects: From Network Interaction to Systemic Transformation

Ria Hardiyati, Trina Fizzanty, and Erman Aminullah

Management of Indonesian ICT Business Incubators: Administrators' Compared to Tenants' Perspective

Emyana Ruth E. Sirait and Faiq Wildana 149-161

SCIENTIFIC REVIEW

The Determinants of Entrepreneurial Success: A Multidimensional Framework

Dyan Vidyatmoko and Pudji Hastuti. $163-178$ 


\title{
if STI POLICY AND MANAGEMENT
}

\section{Building Capacity for Innovation through R\&D Consortia in Health Projects: From Network Interaction to Systemic Transformation**}

\author{
Ria Hardiyati1 ${ }^{1, *}$, Trina Fizzanty ${ }^{2}$, Erman Aminullah $^{3}$ \\ ${ }_{1,2,3}$ Indonesian Institute of Sciences (LIPI), Indonesia
}

\begin{tabular}{|c|c|}
\hline ARTICLE INFO & ABSTRACT \\
\hline $\begin{array}{l}\text { Article History: } \\
\text { Received : } 31 \text { August } 2017 \\
\text { Revised : } 07 \text { December } 2017 \\
\text { Accepted : } 08 \text { December } 2017 \\
\text { Available online : } 15 \text { December } 2017\end{array}$ & $\begin{array}{l}\text { This paper attempts to elucidate the postulation that there is a } \\
\text { continuous trajectory from the network interaction in scientific } \\
\text { research towards the systemic transformation in innovation capacity } \\
\text { building. This study will expose that the availability of research } \\
\text { capacity in certain areas can be developed into innovation capacity, }\end{array}$ \\
\hline $\begin{array}{l}\text { Capacity building } \\
\text { R\&D consortia } \\
\text { Network interaction } \\
\text { Systemic transformation } \\
\text { Life sciences }\end{array}$ & $\begin{array}{l}\text { through R\&D consortia, in which building research capacity is a } \\
\text { long term process of scientific accumulation. This study utilises } \\
\text { two techniques, namely scientometrics and case study in stem cell } \\
\text { as well as vaccine research in order to understand the innovation } \\
\text { capacity. The research capacity in the area of vaccine has long been } \\
\text { developed, from research conducted by individual researchers, on } \\
\text { to research organizations, and further developed into innovation } \\
\text { capacity building by R\&D consortia. However, in areas of stem } \\
\text { cell, there is still a lack of data and information although research } \\
\text { on innovation capacity has been developed by R\&D consortia. } \\
\text { Therefore, further empirical evidence is needed to support the } \\
\text { continuous trajectory. }\end{array}$ \\
\hline
\end{tabular}

C2017 PAPPIPTEK-LIPI All rights reserved

\section{INTRODUCTION}

How and why firms cooperate in R\&D consortia, what are the factors that stimulate firms and R\&D institutes to participate in a R\&D consortia. These questions have been discussed academically and documented in several research findings, among others are in Watanabe, Kishioka, and Nagamatsu (2004) which analysed government-initiated (particularly MITI) R\&D consortia. The effect of

\footnotetext{
** This is the improved paper presented at the $14^{\text {th }}$ International Globelics Conference, on 12-16 October 2016, Bandung, Indonesia.

* Corresponding Author.

E-mail: ria.hardiyati@yahoo.co.id
}

government role in Japan's industrial technology had led to the high-technology miracle in the 1980s. This achievement could be attributed to a virtuous cycle between the quality of the participants in the R\&D consortia and their technology spillover effects. However, the performance of the R\&D consortia - particularly their spillover effects - declined in line with the stagnation of Japan' $s$ industrial $R \& D$, and the shift of consortia's R\&D focus from catch-up type to basic research. A virtuous cycle between the spillover effects and firms' participation in the consortia has changed to a vicious cycle afterwards. 
The role of government in R\&D consortia has been differentiated into "government-coordinated R\&D consortia" and "government-sponsored R\&D consortia". Unlike the governmentsponsored $R \& D$ consortia, which focused on government financial support, the governmentcoordinated R\&D consortia is focused on government decision making, which determines whom to include in the consortia and how tasks are allocated; thus, the government is more directly involved in, and affects the consortium's success. The government's role covers two aspects of coordination: (i) the timing of evaluation of participating firms in a consortium, and (ii) the structure of the consortia. In terms of the timing of evaluation, continuous evaluation is superior, but periodic evaluation is essential. In addition, the effect of the form of the consortia depends on the timing of evaluation (Kim, Bae, \& Yang, 2014).

By observing the sharing of complementary knowledge in consortia, Japanese universities and national research labs generally take an advisory role in a $R \& D$ consortia project. The most important motive of Japanese government-sponsored $R \& D$ consortia participants is the willingness to share knowledge in $R \& D$ consortia when firms possess highly complementary knowledge. Japan's R\&D consortia are concentrated in the electronics, machinery, material, chemical, and energy industries. Meanwhile, the knowledgesharing function is not important for Korea because firms have not accumulated enough $R \& D$ capabilities to share. Korean R\&D consortia are concentrated in the electronics and machinery industries, and they do not fully promote $R \& D$ cooperation and knowledge-sharing (Sakakibara, 2001; Sakakibara \& Cho, 2002).

Viewed from the institutional capacity development needed by the consortia, R\&D consortia in Taiwan creates specific institutions mandated to encourage firms to cooperate in order to raise their technological levels. The basic model of the Taiwanese consortia includes $\mathrm{R} \& \mathrm{D}$ cost sharing and risks reduced policy, by bringing many small firms into a collaborative alliance. Several alliances bring together firms and public sector research institutes, with added organisational input of trade associations, and catalytic financial assistance from government. $\mathrm{R} \& \mathrm{D}$ consortia in Taiwan is an advanced form of "technological learning", in which the most significant players are not the giant firms (as in Japan or Korea), but small and medium sized enterprises instead, whose entrepreneurial flexibility and adaptability have been the key to their success.

From the network embeddedness view, there are three types of networks' embeddedness in R\&D consortia: (i) relational embeddedness: trust based network refers to the high-quality, cohesive social interaction between network members as a community of organizations; (ii) structural embeddedness: network ties conceptually represents the degree to which firms' action is influenced by the macro-network structure in which the firms are embedded, and; (iii) cognitive embeddedness: goals and norms contain the extent to which network members in $R \& D$ consortia are willing to act with shared vision and to engage in mutually beneficial cooperation. The study of R\&D consortia in Taiwan has revealed that focal firms leverage network benefits to improve their technology transfer performance. The network embeddedness developed by focal firms provide opportunities for focal firms to undertake inter-organisational learning (Lin, Fang, Fang, \& Tsai 2009).

After perusing previous research on $R \& D$ consortia, so far there has been no study of $R \& D$ consortia in Indonesia and the researchers have not yet found any research article dealing with the linkage between building research capacity through research networks and building capacity for innovation through R\&D consortia. The objective of this study is to elucidate the postulation that there is a continuous trajectory from the network interaction in scientific research towards the systemic transformation in innovation capacity building. This study will expose that the availability of research capacity in certain areas can be developed into innovation capacity through $R \& D$ consortia, where building research capacity is a long term process of scientific accumulation. 


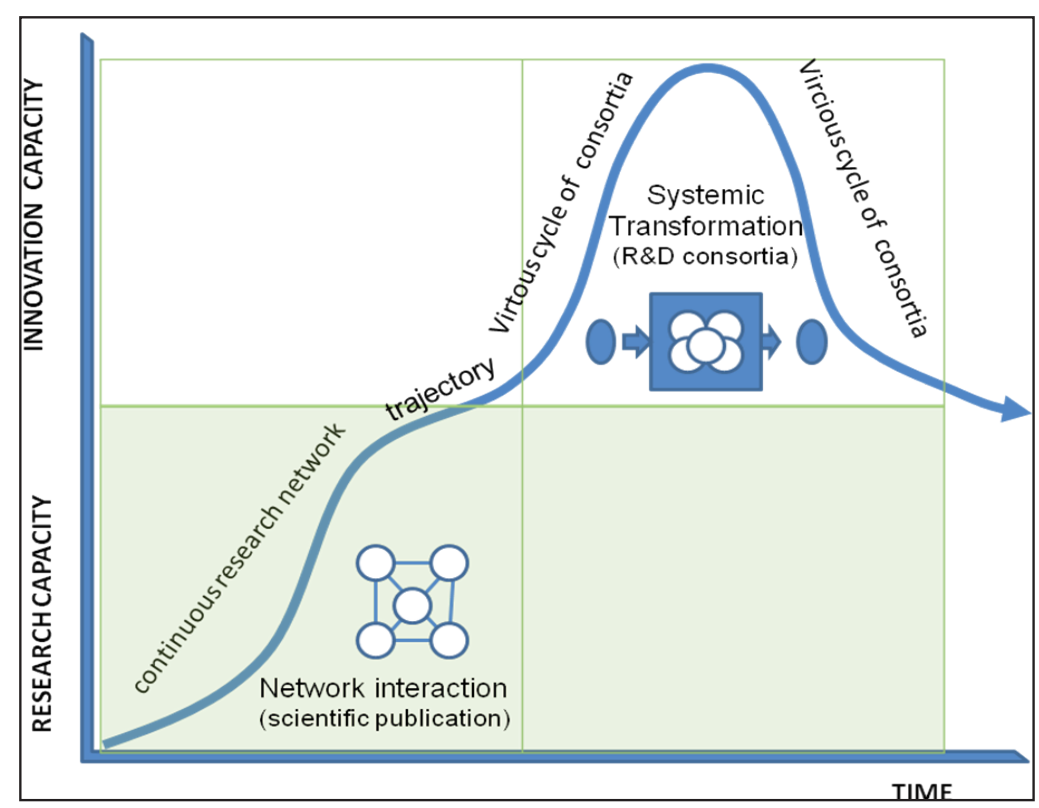

Figure 1. Building Capacity for Innovation through R\&D Consortia

\section{ANALYTICAL FRAMEWORK}

This study starts from the postulation that there is a continuous trajectory from the network interaction in scientific research towards the systemic transformation in innovation capacity building. The network interaction in scientific research can be stagnant or continuous depending on the network embeddedness (Lin, Fang \& Tsai, 2009), while innovation capacity building through $R \& D$ consortia can be a virtuous or vicious cycle, depending on government's role in supporting consortia (Watanabe, Kishioka, \& Nagamatsu, 2004; Kim, Bae \& Yang, 2014). This concept explains that the availability of research capacity in certain areas can be developed into innovation capacity through R\&D consortia, where building research capacity is a long term process of scientific activities accumulation. See Figure 1.

\section{A. Network interaction in scientific research}

The network interaction in scientific research is based on the identification of co-authorship patterns. The social network analysis starts from the premise that the relations between social actors can be described in a graph (Liu, Bollen, Nelson, \& Van de Sompel, 2005). The social network analysis has frequently been conducted in various scientific disciplines (Barabasi, 2002;
Otte \& Rousseau, 2002; Scott, 2000; Wasserman \& Faust, 1994; Watts, 2001). The social network analysis is used to build a network consisting of nodes and edge representing actors (authors/institutions) and actor's interaction (co-authorship), respectively. Nascimento, Sander, and Pound (2003) measure the actor's activity by using the average distance of the path's length in the network produced. In the social network analysis, the distance measurement used in the sociogram is the geodesic distance, which is adopted from the Graph Theory. The geodesic distance is the shortest path between two actors. If one actor is either isolated, unreachable, or has no relations whatsoever with another actor, the actor's geodesic distance is infinite or undefined (Wasserman \& Faust, 1994).

Freeman (1979) argued that the centrality in SNA is one of the measures to see the position of an actor/group in a sociogram. The degree of centrality of an actor is the number of direct relations that belong to an actor. The other centrality measure is the closeness and betweenness. Closeness measures the proximity between actors/ nodes. Betweenness of an actor is the number of an actor's presence in the geodesic (shortest path) of the other actor pairs, compared with the number of the actor pair's geodesic in the network. An individual with the highest betweenness is considered the actor who holds the control of the 


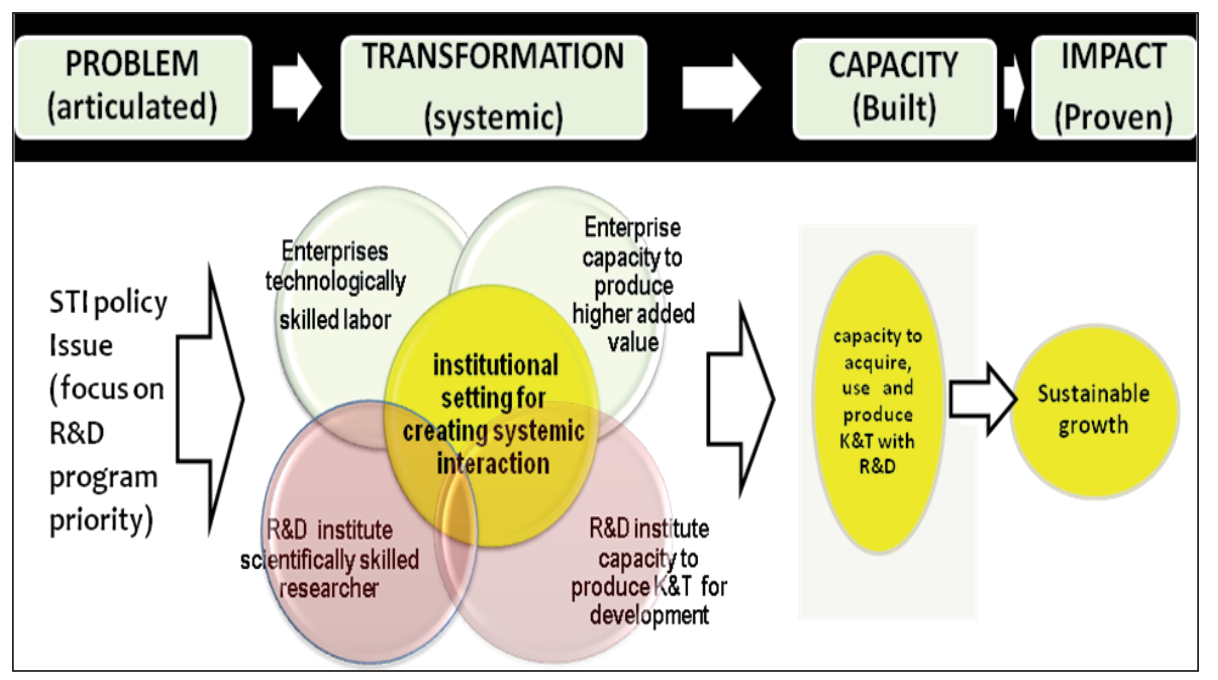

Source: Aminullah \& Fizzanty (2016)

Figure 2. Insitutional Setting for Systemic STI Capacity Building

information flow in the network. Institutions with a high degree of centrality value, small closeness, and high betweenness are the central actors in the network (Small, 1973).

\section{B. Systemic transformation in building capacity for innovation}

The implementation of Indonesian building capacity for innovation is generally a question of the matching-transformation of articulated innovation capacity problems into an innovation capacity that impacts well on society. An innovation capacity problem is more than an $R \& D$ program that needs to be addressed. The matching-transformation should guide the two main parallel components, the private sector and public sector, through an intermediary institution, which match the bilateral relations between them in creating knowledge and technology ( $K \& T)$. The private sector component creates the capacity to acquire and use K\&T mostly through learning or without R\&D by using technologically skilled labor as well as enterprise capacity to produce higher added value. The public sector component creates the capacity to produce $K \& T$ with $R \& D$ by using scientifically skilled researchers in addition to $R \& D$ institute capacity to produce K\&T for development. The existing outcome of building capacity for innovation in private sector, thus far, has produced some social and economic impact, while the public sector capacity still has had a less beneficial impact for the society.

In order to deal with the complex problem of building innovation capacity, this research used the Aminullah and Fizzanty's (2016) model of institutional setting for STI capacity building (see Figure 2.) Despite the constraints of limited researchers' availability and R\&D budget in Indonesia, by upgrading the function of intermediary institution from matching bilateral relations to creating systemic interactions, between public research institutes (PRIs) and industry, there have still been some successful cases of building innovation capacity in life science R\&D. Systemic interaction essentially produces the knowledge and technology capabilities through R\&D to solve the country's pressing social and economic problems, transform the societies, and have a positive impact on the standard of living and quality of life.

Enhancing building capacity for innovation focuses on the availability of institutional setting to create systemic interactions between PRIs and industry. The institutional setting acts more as an intermediary institution than to simply match; it includes directly assisting the industry through various schemes of interaction, such as consortiums, collaborations, partnerships, research grants, contract research, budget sharing, researcher mobility, management mobility, and investment access/guarantee. The institutional 
setting shapes the system of public-private interaction systemically to produce the desired types and levels of knowledge and technology capabilities. For further details, success stories of PRIs assisting industries in developed countries including Germany, USA, Japan, Taiwan, and Australia were confirmed by Intarakumnerd (see Intarakumnerd \& Goto, 2016).

\section{METHODOLOGY}

This study utilised two techniques: (i) scientometrics by using a dataset on scientific publication as an indicator of building research capacity, and (ii) a case study of R\&D consortia in stem cell and vaccine research in order to understand innovation capacity. Firstly, the data of scientific publication in health projects were found in Scopus. The health project belonged to life sciences category, more specifically stem cell and vaccine publications data. The collected data underwent a cleaning process by checking the consistency and conducting harmonisation between the names of the author and institution, as well as by removing duplicated data. Subsequently, the co-authorship social network of institutions would be generated using UCINET. The network would afterwards be analysed using the Social Network Analysis (SNA) to count the centrality of the institutional network: the degree of centrality, closeness, and betweenness.

Secondly, the case study was conducted in selected projects of R\&D consortia, namely stem cell and vaccine projects. The content of information collected from various sources and informants was related to existing and planned $R \& D$ consortia, including identification of participants in R\&D consortia and role of each participants in $R \& D$ consortia, grouped into categories of firms, government, R\&D institutions, universities, intermediary institutions, and foreign actors. The analysis and interpretation of data from case studies were focused on its linkage to the data of building research capacity in areas of stem cell and vaccine by each participants, especially research institutions and universities.

\section{RESULTS AND DISCUSSION}

\section{A. Research capacity building through scientific network}

This study identified research articles from Scopus database published up to 2015. Identification was conducted by keyword search, using "vaccine" and "stem cell" in article titles, abstracts, sorted with "Indonesia" in affiliation country fields. The search yielded 255 articles about vaccine, with 80 institutions and 526 authors, and 142 articles about stem cell, with 41 institutions and 233 authors.

Research articles about vaccine and stem cell were focused in some subject areas. Research about vaccine has $38 \%$ focus in medicine; $26 \%$ in immunology and microbiology; $10 \%$ in veterinary; $9 \%$ in biochemistry, genetics and molecular biology; $7 \%$ in agricultural \& biological sciences; $3 \%$ in pharmacology, toxicology and pharmaceutics; and 7\% in other subject areas. Meanwhile, the research on stem cells mostly focused on the fields of medicine (38\%), immunology \& microbiology (26\%), veterinary (10\%), biochemistry, genetics \& molecular biology (9\%), as well as agricultural and biological sciences $(3 \%)$.

Research articles about vaccine during 19492015 tended to increase. Majority of articles were produced as the collaboration of some authors, both authors from Indonesia and abroad. Ten countries whose authors collaborate frequently with Indonesian authors are United State, Australia, Netherlands, UK, Thailand, Japan, Vietnam, South Korea, Switzerland, and the Philippines. Similarly, research publications about stem cells also increased during 1994-2015. Ten countries whose author collaborate frequently with Indonesian are Japan, United State, Malaysia, Australia, Netherlands, UK, South Africa, China, France, and Germany.

Data of research articles about vaccine and stem cell was analysed using social networking analysis and processed using UCINET and NetDraw. The institutional social network based on a relationship of co-authorship (the collaboration of several authors in one paper) are as follows: the institutional social network of research publication about vaccine consist of 129 institution/ country with 1,232 relation/ties, whereas research 
publication about stem cell consists of 68 institutions/countries with 354 relations/ties. Based on centrality measures in institutional social network, both of vaccine and stem cell, this research found top ten institutions and countries with the best centrality measures, i.e. institution with high value in degree of centrality and betweenness is also with low value in closeness.

Generally, research articles about vaccine shows that institutions with best centrality measures are dominated by university and government R\&D agencies (e.g Ministry of Health and Ministry of Agriculture). An interesting finding revealed that there are $R \& D$ units that come from the private sector, namely PT. Biofarma and several institutions affiliated with Indonesia, which are originated from other countries or international organizations, such as U.S. Naval Medical Research Unit, FAO, and WHO. On the other hand, top ten countries with the best centrality measure do not consist only in developed countries such as United State, Australia, Netherlands, UK, Japan, and China, but also in developing countries in Asia such as Thailand, Vietnam, and the Philippines. It indicates that institutions from Indonesia and other developing countries in Asia have been collaborating in vaccine research and development.

On stem cells research, 10 institutions with best centrality measure are dominated by universities and one government R\&D agency i.e. Indonesian Institute of Sciences (LIPI). Top ten countries with the best centrality measure are dominated by Japan, United State, Netherlands, and Australia. It indicates that Indonesian institutions have been collaborating with countries which are developing stem cells research.

\section{B. Innovation capacity building through $R \& D$ consortia}

Every country has public research institutes (PRIs) as the centres of excellence in specific areas of R\&D. PRIs have the capacity to engage in relevant R\&D for the country's social and economic needs. Indonesian PRIs such as Eijkman Institute conduct $R \& D$ collaboration in stem cell technology and bio-pharmaceutical enterprises, and develop a TB vaccine in cooperation with a university. Promoting life science-based technology consortiums as the centre for the implementation of systemic building capacity for innovation is a workable strategy in Indonesia, and also contributes to solve global issues. This paper presents two case studies of systemic transformation from research capacity into innovation capacity through $R \& D$ consortia in life sciences. The transformation process has been taking place in systemic interactions among consortia participants that have been successful in building innovation capacity to produce medical technology, commercialise new medicines, and has brought a positive impact on the solving of a number of the country's health problems as well as on efforts to improve people's quality of life (see Table 1.)

In the first case study, the National Research Consortia was established in Indonesia to conduct research, develop, and produce a tuberculosis vaccine. The consortium has succeeded in involving various organizations, such as non-ministerial and ministerial $R \& D$ units, industries, higher educational institutions, as well as regional/national science technoparks. Through developing the national vaccine consortium, more opportunities have been opened for Indonesia to get engaged more with international business networks and expand the vaccine business. The Indonesian TB vaccine meets the WHO standard, and has already been exported to many developing countries.

The history of TB vaccine consortia grows from individual research to working group and research consortia. A consortium in TB vaccine is an example from government-led collaboration in the beginning and shifted to business-led collaboration. Two ministries, namely, the Ministry of Health and the Ministry of Research and Technology have been working collaboratively in promoting and supporting research on vaccine. The Ministry of Research and Technology provided grants for the consortia and the Ministry of Health, in this case, the R\&D agency for Health acted as the coordinator of the consortium. The consortia, consisting of 10 members of Indonesian universities, and one national R\&D institution (LIPI) began in 2012 to conduct basic research. Various studies have also been conducted by certain groups. For formulation and proof of 
Table 1.

Role of R\&D Consortia Participants in Systemic Transformation from Research Capacity into Innovation Capacity

\begin{tabular}{lll}
\hline \multicolumn{1}{c}{ CONSORTIUM } & \multicolumn{1}{c}{ TB VACCINES } & \multicolumn{1}{c}{ STEM CELL } \\
\hline LED PARTICIPANT & $\begin{array}{l}\text { R\&D Agency for Helath-Ministry } \\
\text { of health (in the beginning) and } \\
\text { shifted to Business firm }\end{array}$ & UNAIR (ITD Institute for Tropical Disease) \\
\hline GOVERMENT ROLE & $\begin{array}{l}\text { Grant program for consortium } \\
\text { provides by Ministry of Research } \\
\text { and Technology }\end{array}$ & $\begin{array}{l}\text { Public Hospital supports for clinical trials, source for bioma- } \\
\text { terial, producing biomaterial at lab scale }\end{array}$ \\
\hline R\&D INSTITUTIONS ROLE & $\begin{array}{l}\text { 13 national universities conduct } \\
\text { research and provide research } \\
\text { facilities }\end{array}$ & $\begin{array}{l}\text { Adopting and disseminating foreign technology (Resecrh on } \\
\text { Cell Engineering, adopting foreign technology and develop- } \\
\text { ing it in Indonesia and Biomaterial) to researchers and } \\
\text { graduate students. } \\
\text { Developing biomaterial in collaboration between public } \\
\text { hospital and BATAN }\end{array}$ \\
& & $\begin{array}{l}\text { Firm (PT Kimia Farma) support facility for scale up products } \\
\text { (biomaterial) }\end{array}$ \\
\hline FIRMS ROLE & $\begin{array}{l}\text { Producing and commercialising } \\
\text { the vaccine (PT Biofarma) }\end{array}$ & $\begin{array}{l}\text { Partner for increasing Indonesian capability on technology } \\
\text { (stem cell and biomaterial) }\end{array}$ \\
\hline FOREIGN PARTNERS' ROLE & In capacity building & $\begin{array}{l}\text { Indonesia has capacity and succeed to apply stem cell tech- } \\
\text { nology in health sector }\end{array}$ \\
\hline OUTCOME & TB vaccine in pre-clinical trials & Commercialisation new product (biomaterial)
\end{tabular}

concept, foreign firm from Australia has been involved in this consortium. The basic research has been completed in 2015, in which the R\&D Agency of Health acted as the coordinator. In the stage of development (2014-2017), one firm, PT Biofarma, acted as the coordinator to determine potential vaccine and trial for animal. Other members are Agency for Health R\&D, Padjajaran University (Unpad), Gadjah Mada University (UGM) and Airlangga University (Unair). In the next stage (2017-2019), pre-clinical and clinical trials are going to be established by the consortium, and expected to be commercialised in 2020 by the firm.

The second case study is consortia of stem cell research in Indonesia. Four institutions were confirmed to be members of this consortium, including the Research Centre at Unair, the Biomaterial Centre in Soetomo Public Hospital, the National Nuclear Power Agency (Batan), and one company, PT Kimia Farma. The university researchers have conducted intensive research on stem cells, and collaborated with medical researchers and medical doctors in a public hospital (biomedical centre) to develop stem cell technology for medical treatment purposes. Through their partnership with the National Nuclear Power
Agency of Indonesia, the consortium has applied nuclear power to biomaterial development. To scale up the technology innovation on biomaterials, PT Kimia Farma - a state-owned company on pharmacy industry — was also invited to join this consortium.

Indonesia has developed stem cells technology in producing biomaterial for health treatments. The new technology has been developed gradually from individual research to collaborative work between domestic partners (universities, public hospitals, public R\&D, and state-owned companies/ firms) and international partners (the majority are universities from advanced economies). The consortium was led by the Institute of Tropical Disease in Unair and has taken a large part in conducting basic research and training for post graduate students. The leader has brought its capacity on stem cells technology from foreign partners to disseminate it to Indonesian medical doctors and postgraduate students in the universities and public hospitals. The public hospital has a unit operated by researchers in medicine and medical doctors who have the capacity in biomaterial development. This unit intends to develop biomaterial-based stem cell technology, and to reach this goal, they develop collaboration 
with Unair. The public hospital assists clinical trials of biomaterial and provides facilities for pilot plant. In order to scale up the biomaterial, the public hospital is collaborating with a firm. The firm, PT Kimia Farma is a state-owned company, provides equipment for building pilot plant in the public hospital. Both partners have their own capacity, for example researchers in public hospital have obtained training in application of nuclear technology to develop biomaterial from foreign partners, such as National University of Singapore and also from national actors such as Batan. Meanwhile, PT Kimia Farma has experience on biomaterial development resulted from their collaboration with various public hospitals in Indonesia. Currently, the biomaterial is still in clinical trials stage to prove the technology.

PRIs in these two case studies consist of government R\&D in ministerial and non-ministerial institutions, and research centres in public universities. The PRIs have taken four major roles, namely to act as $R \& D$ funding institution, coordinate the R\&D consortia, conduct research for scientific development and technology application, as well as provide education and training.

In many countries, PRIs are one of the important actors in national innovation systems. There are some successful cases of PRIs in other countries, such as Taiwan and Japan. During the catching-up phase, the Industrial Technology Research Institute (ITRI) was successful in its role in incubating Taiwan's electronics industry. Advanced Industrial Science and Technology (AIST) also conducts long term research that provides a significant contribution in creating new industries (Intarakumnerd and Goto, 2016).

\section{Linkage between research and innovation capacity building in life sciences}

The linkage between research and innovation capacity building in life sciences is supported by the following data analysis. In case of vaccine, there is a relationship between research capacity and innovation capacity. The increase in research capacity is indicated by the increase in number of international publication on vaccine involving Indonesian scientists. This is in line with the shift of the research actors' role. The research capacity in the areas of vaccines has been long developed from individual research conducted by researchers. It has been continued into research organisations managed by a working group in universities and research institutions. The vaccine research has been developed into building innovation capacity through R\&D consortia (see Figure 3).

With regard to stem cells research, the data analysis shows that there is a lack of evidence about relation between research capacity and innovation capacity. The number of international publication on stem cells involving Indonesian scientists was stable. However, in the last 6 years there has been a rapid development of international publication number about stem cells. In addition, there has been continuing lack of evidence that individual research capacity has been continued to research organisation, but it is found that research on innovation capacity has been developed by R\&D consortia (see Figure 4.)

The important position of life sciences $R \& D$ for Indonesia has been shown by the international scientific reputation of Indonesian researchers who have been engaged in the area of life sciences R\&D institutions. The most recent data from scientific activities of Indonesian researchers in terms of international collaborations and international publications are in the area of health and medicine, biology, plant sciences, ecology, and environmental sciences. It is therefore an opportunity for international collaboration on $R \& D$ to be further explored and developed in the health sector, agricultural, and marine R\&D (Akil, Hidayat, Simamora, Putera, Wijayanti, \& Kusnandar, 2012). The current countries collaborating with Indonesia in life sciences R\&D are Japan, Germany, France, UK, and the Netherlands. Meanwhile, the countries with the largest number of co-authorship with Indonesia on scientific publication come from Japan, USA, Australia, the Netherlands, and UK. In short, Japan and some EU countries are important counterparts for Indonesia in scientific cooperation.

Currently, initiatives to enhance innovation capacity in Indonesia is focused on intensifying $\mathrm{R} \& \mathrm{D}$ to create life science-based industries. 
Indonesian natural resources-based industries, which are driven by life sciences-based technologies, will further develop faster. Those industries include bio-based chemicals, biomedical, and biotechnology industries. The availability of life science parks (the so called LIPI Cibinong Science Centers) has also been driving the life science-based technology development in Indonesia. In short, in applying a science policy for industrial technology development, Indonesia is enhancing innovation capacity by encouraging R\&D consortia.

\section{CONCLUSION}

Innovation capacity-building is still underway, in the current Indonesian development. Enhancing capacity-building by intensifying R\&D consortia is still a big challenge for Indonesia. Indonesia has the capacity to engage in life science R\&D, especially in the health sectors. Improvements in innovation capacity have been geared towards life science-based technology innovation. Current initiatives to enhance innovation capacity in Indonesia is being supported by intensifying $R \& D$

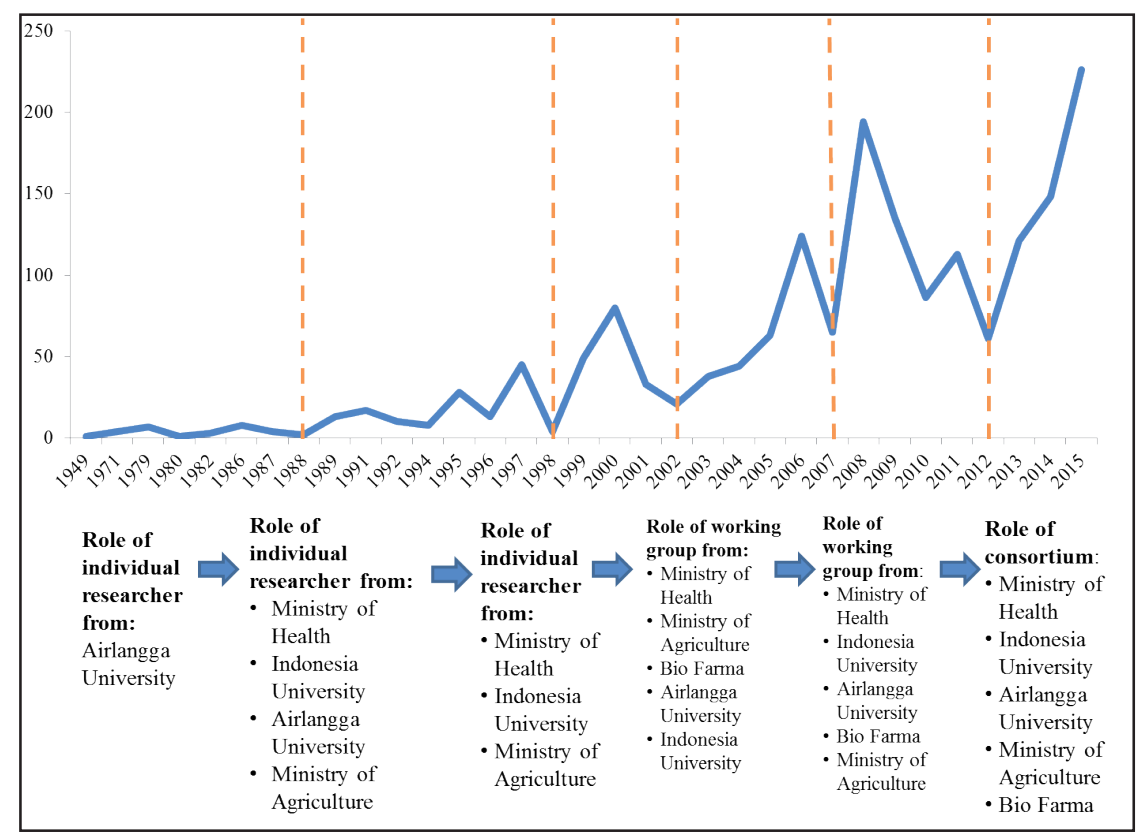

Figure 3. Linkage between Research and Innovation Capacity Building in Vaccine

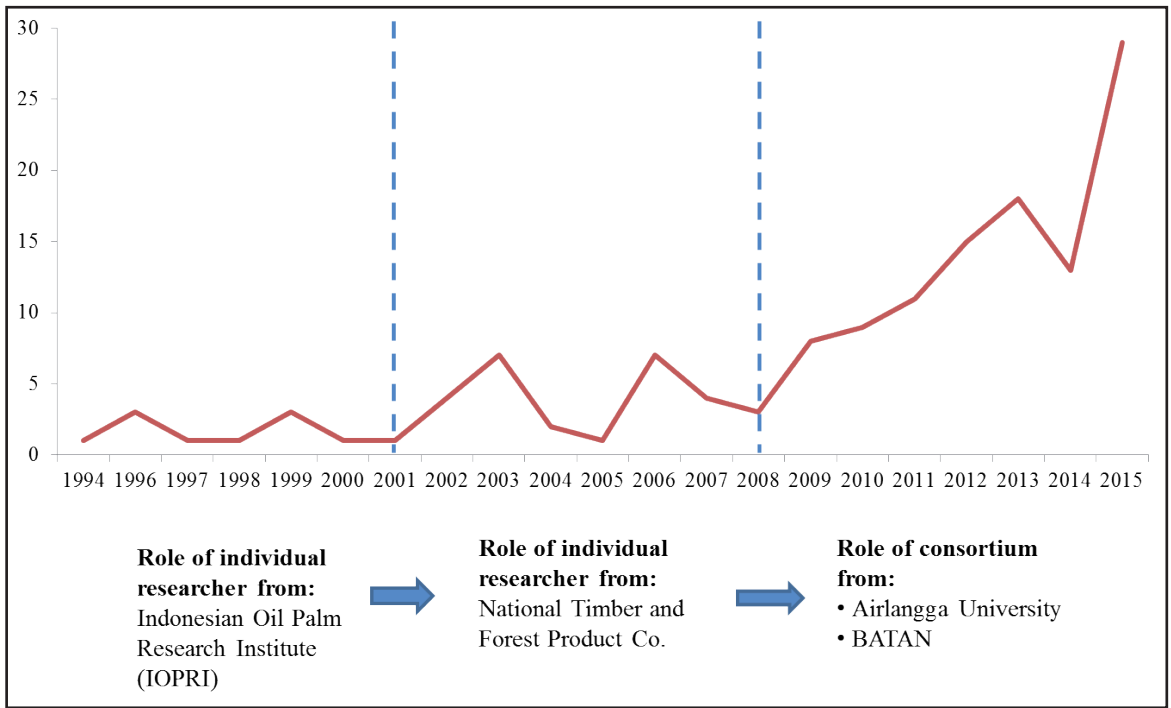

Figure 4. Linkage between Research and Innovation Capacity Building in Stem Cell 
consortia in life sciences, especially vaccine and stem cell.

In vaccine research, R\&D agency of the Ministry of Health has been the best of centrality measures of institution social network. It means that $R \& D$ agency of the Ministry of Health is the institution which has important role in ensuring the quality of vaccine research and has the most intense collaboration with other relevant institutions. Whereas on stem cell research, top ten institutions with the best centrality measures is are only dominated by state universities, but also universities from the eastern part of Indonesia as well as private universities.

The research capacity in the area of vaccines has long been developed, from research conducted by individual researchers, on to research organisations, and further developed into innovation capacity building by R\&D consortia. On the other hand, in area of stem cell, there is still a lack of data and information on individual researchers' capacity as well as research organisations' capacity. However, it is found that research on innovation capacity has been developed by $R \& D$ consortia. Therefore, further empirical evidence is needed to support the continuous trajectory from the network interaction in scientific research towards the systemic transformation in innovation capacity building.

\section{REFERENCES}

Akil, H. A., Hidayat, D., Simamora, N. G., Putera, P. B., Wijayanti, R., \& Kusnandar. (2012). Study on the status of science and technology development in Indonesia. Jakarta: Pappiptek-LIPI.

Aminullah, E. \& Fizzanty, T. (2016). Enhancing STI capacity: Intensifying $R \& D$ for sustainable growth in Indonesia. Transnational lecture series on the internationalization of science, Technology and Innovation. Vienna: Austrian Institute for International Affairs (AIIA). Vienna, 25/04/2016. Retrieved from: http:// www.oiip.ac.at/fileadmin/Unterlagen/Dateien/ Summaries/Summary_Indonesia.pdf.

Barabasi, A .L. (2002). Linked-the new science of networks. Cambridge, MA: Perseus Publishing.

Freeman, L. C. (1979). Centrality in social networks conceptual clarification. Social Networks, 1, 215-239.
Intarakumnerd, P. \& Goto, A. (2016). Role of public research institute in national innovation system in industrialized countries: The cases of Fraunhover, NIST, CSIRO, AIST, and ITRI. Tokyo: RIETI, Discussion paper series 16-E005 .

Kim, Ji-hyun, Bae, S. J. \& Yang, J. S. (2014). Government roles in evaluation and arrangement of R\&D consortia. Technological Forecasting \& Social Change, 88, 202-215.

Lin, J. L., Fang, S. C., Fang, S. R., \& Tsai, F. S. (2009). Network embeddedness and technology transfer performance in R\&D consortia in Taiwan. Technovation, 29, 763-774.

Liu, X., Bollen, J., Nelson, M. L., Van de Sompel, H. (2005). Co-Authorship networks in digital library research community. Information Processing and Management, 41, 1462-1480.

Mathews, J. A. (2002). The origins and dynamics of Taiwan's R\&D consortia. Research Policy, 31, 633-651.

Nascimento, M. A., Sander, J., \& Pound, J. (2003). Analysis of SIGMOD's co-authorship graph. SIGMOD Record, 32(3), 8-10.

Otte, E., \& Rousseau, R. (2002). Social network analysis: A powerful strategy, also for the information sciences. Journal of Information Science, 28(6), 441-453.

Sakakibara, M. (2001). Cooperative research and development: Who participates and in which industries do projects take place?. Research Policy, 30, 993-1018.

Sakakibara, M. \& Cho, D. S. (2002). Cooperative R\&D in Japan and Korea: A comparison of industrial policy. Research Policy, 31, 673-692.

Scott, J. (2000). Social network analysis: A handbook. London: Sage Publications.

Small, H. (1973). Co-citation in the scientific literature: A new measure of the relationship. Journal of the American Society for Information Science, 24(4), 265-269. http://doi.org/10.1002/ asi.4630240406

Wasserman, S., \& Faust, K. (1994). Social network analysis: Methods and applications. Cambridge: Cambridge University Press.

Watanabe, C,. Kishioka, M. \& Nagamatsu, A. (2004). Effect and limit of the government role in spurring technology spillover: A case of R\&D consortia by the Japanese government. Technovation, 24, 403-420.

Watts, D. (2001). Small worlds: The dynamics of networks between order and randomness. New Jersey: Princeton University Press. 